\title{
Edukasi Perilaku Hidup Bersih Dan Sehat Dalam Rumah Tangga Terhadap Pengetahuan Kader Kesehatan
}

\author{
${ }^{1}$ Rusdianingseh", ${ }^{2}$ Nety Mawarda Hatmanti, ${ }^{3}$ Didik Dwi Winarno \\ ${ }^{1}$ Program Studi Profesi Ners FKK UNUSA \\ ${ }^{2}$ Program Studi S1 Keperawatan FKK UNUSA \\ ${ }^{3} \mathrm{PKM}$ Kebonsari Surabaya \\ *Email Korespondensi: rusdia@unusa.ac.id
}

\section{Kata kunci : PHBS \\ Rumah Tangga, \\ pengetahuan, kader \\ kesehatan \\ Keywords : Household \\ PHBS, knowledge, health cadres}

Info Artikel:

Tanggal dikirim:

20 September 2021

Tanggal direvisi:

12 Oktober 2021

Tanggal diterima :

08 November 2021

\section{DOI Artikel:}

10.33862/citradelima. v5i2. 240

Halaman: 61-66

\section{Abstrak}

PHBS (Perilaku Hidup Bersih dan Sehat) merupakan hal yang sangat penting dalam rumah tangga. Masa pandemi covid-19 membuat kita lebih lama tinggal di dalam rumah sehingga PHBS rumah tangga perlu ditingkatkan, sebagai salah satu hal yang dapat meningkatkan kesehatn keluarga. Tujuan dalam penelitian ini adalah untuk menegetahui pengaruh edukasi PHBS rumah tangga terhadap tingkat pengetahuan kader kesehatan sebelum dan setelah diberikan edukasi. Jenis penelitian ini adalah analitik dengan teknik quasy eksperimen dengan pendekatan pre post test two groups. Populasi target adalah seluruh kader kesehatan yang aktif di wilayah Kebonsari Surabaya dengan kriteria yang ditetapkan oleh peneliti adalah usia dewasa di atas 21-59 tahun, bisa membaca dan menulis dengan baik, tinggal di wilayah Kebonsari surabaya. Sampel sebesar 66 responden yang dibagi menjadi dua kelompok yaitu kelompok intervensi 33 responden dan kelompok kontrol 33 responden. Instrumen yang digunakan adalah kuesioner tingkat pengetahuan yang diberikan sebelum dan setelah intervensi edukasi PHBS rumah tangga. Data dianalisis menggunakan uji Wilcoxon Signed Rank dan Mann Whitney dengan tingkat kemaknaan $\alpha=0,05$. Hasil uji beda post-test kelompok ekperimen dan kontrol menggunakan uji Mann Whitney didapatkan nilai $\rho=0,000$ dengan tingkat kemaknaan $\alpha=0,05$ yang berarti ada pengaruh edukasi PHBS rumah tangga melalui lembar balik terhadap pengetahuan kader kesehatan. Pengetahuan adalah hasil dari pengindraan, hasil tau seseorang terhadap objek melalui indra yang dimiliki (mata, hidung, telinga) sehingga menghasilkan pengetahuan yang sangat dipengaruhi oleh intensitas perhatian terhadap objek tersebut. Simpulan dari penelitian ini bahwa terdapat pengaruh edukasi PHBS rumah tangga melalui media lembar balik terhadap pengetahuan kader kesehatan.

\section{Education of Clean and Healthy Lifestyle in the Household on Knowledge of Health Cadres}

\begin{abstract}
PHBS (Clean and Healthy Living Behavior) is very important in the household. The Covid-19 pandemic period has made us stay at home longer so that household PHBS needs to be improved, as one of the things that can improve family health. The purpose of this study was to determine the effect of household PHBS education on the level of knowledge of health cadres before and after being given education. This type of research is analytic with a quasi-experimental technique with a pre-post-test two groups approach. The target population is all active health cadres in the Kebonsari area of Surabaya with the criteria set by the researchers are adults over 21-59 years old, can read and write well, live in the Kebonsari area of Surabaya. The sample was 66 respondents who were divided into two groups, namely the intervention group 33 respondents and the control group 33 respondents. The instrument used was a knowledge level questionnaire that was given before and after the household PHBS education intervention. Data were analyzed using the Wilcoxon Signed Rank and Mann Whitney test with a significance level of $=0.05$. The results of the post-test difference between the experimental and control groups using the Mann Whitney test obtained a value of $=0.000$ with a significance level of $=0.05$, which means that there is an influence of household PHBS education through flipcharts on the knowledge of health cadres. Knowledge is the result of sensing, the result of someone's knowledge of objects
\end{abstract}


through their senses (eyes, nose, ears) so as to produce knowledge that is strongly influenced by the intensity of attention to the object. The conclusion of this study is that there is an influence of household PHBS education through flipchart media on the knowledge of health cadres.

\section{PENDAHULUAN}

Corona virus disease atau covid-19 merupakan pandemi penyakit yang terjadi secara global atau menyebar luas di seluruh dunia. Penularan covid-19 sangat cepat melalui droplet. Pandemi ini menyebabkan bencana bagi seluruh masyarakat, menyebabkan kematian yang cukup tinggi termasuk di Indonesia. Penyakit ini akan sangat mudah menyebar pada individu yang mempunya kontak erat dengan penderita seperti dalam keluarga. Penularan virus covid-19 ini dapat dicegah dengan penerapan perilaku hidup bersih dan sehat (PHBS)dalam keluarga atau rumah tangga.

Data dari Profil Kesehatan Jawa Timur tahun 2018 disebutkan bahwa rumah tangga yang melakukan PHBS sebesar $56,13 \%$. Berdasarkan wawancara dengan kader kesehatan Kebonsari Surabaya, menyatakan bahwa masih ada beberapa keluarga yang belum menerapkan PHBS rumah tangga. Kader kesehatan juga belum semuanya paham tentang PHBS rumah tangga di masa pandemi covid-19.

Upaya mencegah penularan covid-19 maka berbagai tindakan preventif harus dilaksanakan baik oleh pemerintah maupun masyarakat termasuk keluarga. Salah satu upaya dalam keluarga/ rumah tangga adalah dengan menerapkan pola hidup bersih dan sehat (PHBS) rumah tangga. PHBS dalam rumah tangga merupakan upaya untuk memberdayakan anggota rumah tangga agar tahu, mau dan mampu mempraktikkan perilaku hidup bersih dan sehat serta berperan aktif dalam gerakan kesehatan di masyarakat. PHBS di Rumah Tangga dilakukan untuk mencapai rumah tangga berperilaku hidup bersih dan sehat (Gani et al., 2015).

PHBS dijalankan melalui proses peningkatan kesadaran dan kemampuan setiap individu dalam hal kesehatan dan perilaku hidup sehat dan bersih dalam kehidupan seharai-hari termasuk dalam lingkungan keluarga. Menurut Dinas Kesehatan Provinsi Jawa Timur tahun 2020, PHBS rumah tangga pada masa adaptasi kebiasaan baru pandemi covid-19 ini ada 8 (delapan) indikator. Sosialisasi indikatro PHBS ini bisa dimulai dari kesehatan kesehatan di komunitas.

Kader kesehatan merupakan laki-laki atau wanita yang dipilih oleh masyarakat dan dilatih untuk menemukan dan menangani masalah kesehatan yang terjadi di masyarakat. Kader kesehatan atau Posyandu, menurut Depkes RI (2020) adalah anggota masyarakat yang dipilih dari dan oleh masyarakat, mau dan mampu bekerja bersama dalam berbagai kegiatan kemasyarakatan secara sukarela. Pemberian edukasi/ pendidikan kesehatan tentang PHBS rumah tangga dapat dilakukan dengan berbagai metode dan media, salah satunya dengan media cetak (Buku PHBS Pada Masa AKB-No 2.Pdf, 2020). Menurut Artanti, R. (2013) dalam penelitiannya menunjukkan bahwa ada pengaruh pemberian pendidikan kesehatan tentang PHBS rumah tangga dengan peningkatan pengetahuan keluarga (Artanti, 2013). Penelitian yang dilakukan oleh Damaiyanti, S., \& Hardyanti, C. (2015). menyebutkan bahwa ada hubungan yang bermakna anta pengetahuan dan peran kader dengan penerapan PHBS rumah tangga. Berdasarkan pernyataan di atas maka perlu dilakukan peningkatan pengetahuan kader kesehatan tentang PHBS rumah tangga melalui edukasi, diharapkan kader kesehatan akan mensosialisasikan kemudian di masyarakat setempat (Damaiyanti, 2014).

\section{METODE}

Jenis penelitian ini adalah analitik dengan teknik quasy eksperimen dengan pendekatan pre post test two groups design. Populasi target adalah seluruh kader kesehatan yang aktif di wilayah Kebonsari Surabaya dengan kriteria yang ditetapkan oleh peneliti adalah usia dewasa di atas 21-59 tahun, bisa membaca dan menulis dengan baik, tinggal di wilayah Kebonsari surabaya. Sampel sebesar 66 responden yang diambil dengan teknik simple random sampling. Sample dibagi menjadi dua kelompok yaitu kelompok intervensi sebesar 33 da kelompok kontrol sebesar 33.

Kelompok intervensi diberikan pre test-intervensipost tes. Intervensi yang diberikan berupa lembar balik tentang PHBS Rumah Tangga. Sedangkan pada kelompok kontrol diberikan pre test dan post test. Instrumen yang digunakan adalah kuesioner tingkat pengetahuan yang diberikan sebelum dan setelah intervensi edukasi PHBS rumah tangga dengan media cetak lembar balik. Variabel independen penelitian adalah edukasi PHBS rumah tangga, dan variabel dependennya adalah pengetahuan.

\section{HASIL DAN PEMBAHASAN \\ Hasil}

Tabel 1. Karakteristik Responden Jenis Kelamin

\begin{tabular}{cccccc}
\hline No & JK & \multicolumn{2}{c}{\begin{tabular}{c} 
Kelompok \\
\multicolumn{2}{c}{ Kelompok } \\
\end{tabular}} & & \multicolumn{2}{c}{ Eksperimen } & \multicolumn{2}{c}{ Kontrol } \\
\cline { 3 - 6 } & $\mathrm{f}(\mathrm{n})$ & $\%$ & $\mathrm{f}(\mathrm{n})$ & $\%$ \\
\hline 1 & Perempuan & 33 & 100 & 33 & 100 \\
\hline
\end{tabular}

http://jurnalilmiah.stikescitradelima.ac.id/index.php/JI Vol.5 No.2 Januari 2022 


\begin{tabular}{lllll}
\hline Jumlah & 33 & 100 & 33 & 100
\end{tabular}

Sumber: Data Primer September 2021

Berdasarkan Tabel 1 menunjukkan bahwa pada kelompok eksperimen dan kelompok kontrol dari 66 responden semuanya adalah perempuan (100\%).

Tabel 2. Karakteristik Responden Berdasarkan Usia

\begin{tabular}{|c|c|c|c|c|c|}
\hline \multirow[t]{2}{*}{ No } & \multirow[t]{2}{*}{ Usia } & \multicolumn{2}{|c|}{$\begin{array}{l}\text { Kelompok } \\
\text { Eksperimen }\end{array}$} & \multicolumn{2}{|c|}{$\begin{array}{c}\text { Kelompok } \\
\text { Kontrol }\end{array}$} \\
\hline & & $f(n)$ & $\%$ & $\mathrm{f}(\mathrm{n})$ & $\%$ \\
\hline 1. & $26-35$ th & 11 & 33,3 & 7 & 21,3 \\
\hline 2. & $36-45$ th & 20 & 60,7 & 23 & 69,7 \\
\hline 3. & $46-55$ th & 2 & 6 & 3 & 9 \\
\hline \multicolumn{2}{|c|}{ Jumlah } & 33 & 100 & 33 & 100 \\
\hline
\end{tabular}

Sumber: Data Primer September 2021

Berdasarkan Tabel 2 menunjukkan bahwa pada kelompok eksperimen dan kelompok kontrol dari 66 responden sebagian besar berusia antara 36-45 tahun.

Tabel 3. Karakteristik Responden Berdasarkan Pendidikan

\begin{tabular}{clcccc}
\hline No & Pendidikan & \multicolumn{2}{c}{$\begin{array}{c}\text { Kelompok } \\
\text { Eksperimen }\end{array}$} & \multicolumn{2}{c}{ Kelompok } \\
& & Kontrol \\
\cline { 3 - 6 } & & $\mathrm{f}(\mathrm{n})$ & $\%$ & $\mathrm{f}(\mathrm{n})$ & $\%$ \\
\hline 1. & $\begin{array}{l}\text { SMP } \\
\text { Sederajat }\end{array}$ & 11 & 33,3 & 10 & 30,3 \\
2. & $\begin{array}{l}\text { SMA } \\
\text { Sederajat }\end{array}$ & 22 & 66,7 & 23 & 69,7 \\
\hline \multicolumn{2}{c}{ Jumlah } & 33 & 100 & 33 & 100 \\
\hline
\end{tabular}

Sumber: Data Primer September 2021

Berdasarkan Tabel 3 menunjukkan bahwa pada kelompok eksperimen dan kelompok kontrol dari 66 responden sebagian besar berpendidikan SMA sederajat.

Tabel 4. Distribusi Frekuensi Responden Berdasarkan Tingkat Pengetahuan Tentang PHBS Rumah Tangga Kelompok Eksperimen

\begin{tabular}{|c|c|c|c|c|c|}
\hline \multirow[t]{2}{*}{ No } & \multirow{2}{*}{$\begin{array}{l}\text { Tingkat } \\
\text { Pengetahuan } \\
\text { Tentang } \\
\text { PHBS Rumah } \\
\text { Tangga }\end{array}$} & \multicolumn{2}{|c|}{ Sebelum } & \multicolumn{2}{|c|}{ Sesudah } \\
\hline & & $\mathrm{F}(\mathrm{n})$ & $\%$ & $\mathrm{~F}(\mathrm{n})$ & $\%$ \\
\hline 1. & Baik & 0 & 0 & 16 & 48,5 \\
\hline 2. & Cukup & 1 & 3 & 9 & 27,3 \\
\hline 3. & Kurang & 32 & 97 & 8 & 24,2 \\
\hline \multicolumn{2}{|c|}{ Jumlah } & 33 & 100 & 33 & 100 \\
\hline $\begin{array}{l}\text { Uji s } \\
\text { Asyn } \\
\text { Negc } \\
\text { Posi } \\
\text { Ties }\end{array}$ & $\begin{array}{l}\text { istik Wilcoxon } \\
\text { Sig (2-tailed) } \\
\text { e rank } \\
\text { e rank }\end{array}$ & $\begin{array}{l}\text { ign } R a \\
=0,00 \\
=1 \\
=25 \\
=7\end{array}$ & Tes & & \\
\hline
\end{tabular}

Sumber: Data Primer September 2021
Berdasarkan tabel 4 menunjukkan bahwa pada kelompok ekperimen sebelum diberikan edukasi didapatkan hampir seluruhnya (97\%) responden memiliki tingkat pengetahuan kurang tentang PHBS Rumah Tangga dan sebagian kecil (3\%) responden memiliki tingkat pengetahuan cukup. Setelah diberikan edukasi hampir setengahnya $(48,5 \%)$ memiliki tingkat pengetahuan baik, haampir setengahnya (27,3\%) memiliki tingkat pengetahuan cukup dan sebagian kecil $(24,2 \%)$ memiliki tingkat pengetahuan kurang tentang PHBS Rumah Tangga. Hasil uji Wilcoxon sign rank test dengan SPSS for windows dengan tingkat kemaknaan $\alpha=0,05$ didapatkan nilai $\rho=0,000$ $(0,000<0,05)$ maka $\mathrm{H}_{0}$ ditolak yang berarti ada pengaruh edukasi PHBS Rumah Tangga terhadap pengetahuan kader kesehatan.

Tabel 5. Distribusi Frekuensi Responden Berdasarkan Tingkat Pengetahuan Tentang PHBS Rumah Tangga Kelompok Kontrol

\begin{tabular}{|c|c|c|c|c|c|}
\hline \multirow[t]{2}{*}{ No } & \multirow[b]{2}{*}{$\begin{array}{l}\text { Tingkat } \\
\text { Pengetahuan } \\
\text { Tentang } \\
\text { PHBS } \\
\text { Rumah } \\
\text { Tangga }\end{array}$} & \multicolumn{2}{|c|}{ Sebelum } & \multicolumn{2}{|c|}{ Sesudah } \\
\hline & & $\mathrm{f}(\mathrm{n})$ & $\%$ & $\mathrm{~F}(\mathrm{n})$ & $\%$ \\
\hline 1. & Baik & 0 & 0 & 0 & 0 \\
\hline 2. & Cukup & 1 & 3 & 1 & 3 \\
\hline 3. & Kurang & 32 & 97 & 32 & 97 \\
\hline \multicolumn{2}{|c|}{ Jumlah } & 33 & 100 & 33 & 100 \\
\hline $\begin{array}{l}\text { Uji } \\
\text { Asy } \\
\text { Neg } \\
\text { Pos } \\
\text { Ties }\end{array}$ & $\begin{array}{l}\text { atistik Wilcoxo } \\
\text { pig (2-tailed) } \\
\text { ive rank } \\
\text { ve rank }\end{array}$ & $\begin{array}{l}\text { Sign } K \\
=1 . \\
=0 \\
=0 \\
=33\end{array}$ & $\begin{array}{l}k T e s \\
j\end{array}$ & & \\
\hline
\end{tabular}

Sumber : Data primer, September 2021

Berdasarkan tabel pada kelompok kontrol hasil pretest dan postest 5 menunjukkan bahwa hampir seluruhnya $(97 \%)$ responden memiliki tingkat pengetahuan kurang dan sebagian kecil (3\%) memiliki tingkat pengetahuan cukup tentang PHBS Rumah Tangga. Berdasarkan tabel tersebut bahwa hasil penelitian ini tidak menunjukkan perubahan tingkat pengetahuan pada hasil posttest. Hasil uji wilcoxon sign rank test dengan SPSS for Windows dengan tingkat kemaknaan $\alpha=0,05$ didapatkan nilai $\rho=1,000$ $(1,000>0,05)$ maka $\mathrm{H}_{0}$ diterima yang berarti tidak ada pengaruh edukasi PHBS Rumah Tangga terhadap pengetahuan kader kesehatan.

http://jurnalilmiah.stikescitradelima.ac.id/index.php/JI Vol.5 No.2 Januari 2022 
Tabel 6. Distribusi Perbedaan Tingkat Pengetahuan Tentang PHBS Rumah Tangga (Pre Test) Antara Kelompok Eksperimen dan Kelompok Kontrol

\begin{tabular}{llcccc}
\hline No & $\begin{array}{l}\text { Tingkat } \\
\text { Pengetahuan }\end{array}$ & \multicolumn{2}{c}{$\begin{array}{c}\text { Kelompok } \\
\text { Eksperimen }\end{array}$} & \multicolumn{2}{c}{$\begin{array}{c}\text { Kelompok } \\
\text { Kontrol }\end{array}$} \\
\cline { 2 - 5 } & Tentang & $\mathrm{f} \mathrm{(n)}$ & $\%$ & $\mathrm{f}(\mathrm{n})$ & $\%$ \\
& $\begin{array}{l}\text { PHBS } \\
\text { Rumah }\end{array}$ & & & & \\
& Tangga & & & & \\
\hline 1. & Baik & 0 & 0 & 0 & 0 \\
2. & Cukup & 1 & 3 & 1 & 3 \\
3. & Kurang & 32 & 97 & 32 & 97 \\
\hline Jumlah & 33 & 100 & 33 & 100 \\
\hline \multicolumn{5}{r}{ uji mann whitney didapatkan $\rho=1,000$} \\
\hline
\end{tabular}

Sumber : Data primer, September 2021

Berdasarkan tabel 6 menunjukkan bahwa sebelum diberikan edukasi pada kelompok eksperimen dan kelompok kontrol didapatkan hampir seluruhnya (97\%) memiliki tingkat pengetahuan kurang dan sebagian kecil (3\%) memiliki tingkat pengetahuan kurang tentang PHBS Rumah Tangga. Hasil uji mann whitney dengan SPSS for Windows dengan tingkat kemaknaan $\alpha=0,05$ didapatkan nilai $\rho=1,000(1,000<0,05)$ maka $\mathrm{H}_{0}$ diterima yang berarti tidak ada perbedaan tingkat pengetahuan tentang PHBS Rumah Tangga pada kelompok eksperimen dan kelompok kontrol sebelum diberikan edukasi.

Tabel 7. Distribusi Perbedaan Tingkat Pengetahuan Tentang PHBS Rumah Tangga (Post Test) Antara Kelompok Eksperimen dan Kelompok Kontrol

\begin{tabular}{llcccc}
\hline No & Tingkat & \multicolumn{2}{c}{$\begin{array}{c}\text { Kelompok } \\
\text { Eksperimen }\end{array}$} & \multicolumn{2}{c}{$\begin{array}{c}\text { Kelompok } \\
\text { Kontrol }\end{array}$} \\
\cline { 2 - 6 } & $\begin{array}{l}\text { Pengetahuan } \\
\text { Tentang }\end{array}$ & $\mathrm{f}(\mathrm{n})$ & $\%$ & $\mathrm{~F}(\mathrm{n})$ & $\%$ \\
& PHBS & & & & \\
& Rumah & & & & \\
& Tangga & & & & \\
\hline 1. & Baik & 16 & 48,5 & 0 & 0 \\
2. & Cukup & 9 & 27,3 & 1 & 3 \\
3. & Kurang & 8 & 24,2 & 32 & 97 \\
\hline Jumlah & 33 & 100 & 33 & 100 \\
\hline \multicolumn{5}{r}{} & uji mann whitney didapatkan $\rho=0,000$ \\
\hline
\end{tabular}

Sumber : Data primer, September 2021

Berdasarkan tabel 7 menunjukkan bahwa sesudah diberikan edukasi pada kelompok eksperimen hampir setengahnya $(48,5 \%)$ memiliki tingkat pengetahuan baik, hampir setengahnya $(27,3 \%)$ memiliki tingkat pengetahuan cukup dan sebagian kecil $(24,2 \%)$ memiliki tingkat pengetahuan kurang tentang PHBS Rumah Tangga. Pada kelompok kontrol menunjukkan hampir seluruhnya $(97 \%)$ memiliki tingkat pengetahuan kurang dan sebagian kecil (3\%) memiliki tingkat pengetahuan cukup tentang PHBS Rumah Tangga. Hasil uji mann whitney dengan SPSS for Windows dengan tingkat kemaknaan $\alpha=0,05$ didapatkan nilai $\rho=0,000$ $(0,000<0,05)$ maka $\mathrm{H}_{0}$ ditolak yang berarti ada perbedaan tingkat pengetahuan tentang PHBS Rumah Tangga pada kelompok eksperimen dan kelompok kontrol sesudah deberikan edukasi.

\section{Pembahasan}

\section{a. Tingkat pengetahuan sebelum diberikan intervensi}

Berdasarkan tabel 4 menunjukkan bahwa pada kelompok ekperimen dan kelompok kontrol sebelum diberikan intervensi didapatkan hampir seluruhnya (97\%) responden memiliki tingkat pengetahuan kurang tentang dan sebagian kecil $(3 \%)$ responden memiliki tingkat pengetahuan cukup.

Pengetahuan yang kurang pada hampir seluruh responden tersebut dikarenakan responden hanya mengetahui dan menghafal sebagian indikator PHBS rumah tangga antara lain, mencuci tangan yang bersih, memberi ASI eksklusif dan menimbang balita. Pendidikan kesehatan tentang PHBS sudah perna didapatkan oleh kader namun selama pandemi covid-19, kegiatan mereka kosong sehingga banyak hal yang terlupakan.

Pengetahuan adalah hasil dari pengindraan manusia, atau hasil tau seseorang terhadap objek melalui indra yang dimiliki (mata, hidung, telingah, dan sebagainya) dan sendirinya pada waktu pengindraan sehingga menghasilkan pengetahuan yang sangat dipengaruhi oleh intensitas perhatian persepsi terhadap objek. Sebagian besar pengetahuan seseorang diperoleh melalui indra pendengaran (telinga) (Notoatmodjo, 2014). Pengetahuan adalah suatu hasil tau dari manusia atas penggabungan atau kerjasama antara suatu subyek yang mengetahui dan objek yang diketahui. Segenap apa yang diketahui tentang sesuatu objek tertentu (Nurroh, 2017).

Menurut asumsi peneliti bahwa penyegaran kader perlu dilakukan kembali karena selama pandemi covid-19 kegiatan kader banyak yang kosong sehingga pengetahuannya agak menurun. Beberapa metode edukasi dapat diberikan dengan tetap mematui protokol kesehatan misalnya dengan memberikan lembar balik online.

Menurut Saleh, A., \& Kunoli, F. J. (2018), untuk mewujudkan PHBS secara terencana, tepat berdasarkan situasi daerah maka diperlukan pemahaman dan tahapan. Memperkenalkan kepada masyarakat gagasan dan teknik perilaku Program Perilaku Hidup Bersih dan Sehat (PHBS), yang merupakan pendekatan terencana untuk mencegah penyakit melalui pengadopsian perubahan perilaku oleh masyarakat secara meluas. Program ini dimulai dari apa yang diketahui, diinginkan, dan dilakukan masyarakat (Saleh \& Kunoli, 2019).

Perencanaan suatu program promosi hygiene untuk masyarakat dilakukan berdasarkan jawaban http://jurnalilmiah.stikescitradelima.ac.id/index.php/JI Vol.5 No.2 Januari 2022 
atau pertanyaan diatas atau bekerjasama dengan pihak yang terlibat, untuk itu diperlukan pesan pesan sederhana, positif, menarik yang dirancang untuk dikomunikasikan lewat sarana lokal seperti poster, leaflet dan sebagainya (Buku PHBS Pada Masa AKB-No 2.Pdf, 2020).

\section{b. Tingkat pengetahuan setelah diberikan intervensi}

Berdasarkan tabel 5 menunjukkan bahwa pada kelompok eksperimen sesudah diberikan edukasi melalui media lembar balik menunjukkan hampir setengahnya $(48,5 \%)$ responden memiliki tingkat pengetahuan baik, $(27,3 \%)$ responden memiliki tingkat pengetahuan cukup dan $(24,2 \%)$ responden memiliki tingkat pengetahuan kurang. Pada kelompok kontrol didapatkan hampir seluruhnya (97\%) responden memiliki tingkat pengetahuan kurang dan sebagian kecil (3\%) responden memiliki tingkat pengetahuan cukup.

Berdasarkan Notoadmojo (2010), tingkat pengetahuan seseorang dipengaruhi oleh faktor pendidikan yaitu bimbingan yang diberikan seseorang terhadap perkembangan orang lain sehingga seseorang tersebut menjadi tahu. Sesuai dengan hasil penelitian ini bahwa telah terjadi perubahan pengetahuan sebelum dan sesudah diberikan pendidikan kesehatan mengenai PHBS rumah tangga melalui media lembar balik pada kader kesehatan (Notoatmodjo, 2010).

Penerapan perilaku hidup bersih sehat (PHBS) terdapat faktor-faktor yang mempengaruhi. Lawrence Green dalam Notoadmodjo (2010), membedakan adanya dua determinan masalah kesehatanya itu factor perilaku (behavioral factors) dan faktor non perilaku (non behavioralfactors). Green men-jelaskan bahwa faktor perilaku ditentukan oleh tiga factor utama yaitu faktor predisposisi, faktor pendukung atau pemungkin dan faktor penguat. Faktor predisposisi yaitu ter-jadinya perilaku seseorang antara lain pengetahuan, sikap, persepsi, keyakinan, ke-percayaandanjuganilanilaitradisi. Sedangkan faktor pemungkin yaitu hubungan antara konsep pengetahuan dan praktek. Dan faktor penguat yang mendorong untuk bertindak untuk mencapai suatu tujuan yang terwujud dalam peran keluarga terutama orang tua, kader kesehatan dan petugas kesehatan (Saleh \& Kunoli, 2019).

Menurut suatu penelitian ada keeratan hubungan antara pengetahuan dalam upaya memperbaiki perilaku, meningkatkan pengetahuan akan memberi hasil yang cukup berarti untuk memperbaiki perilaku. Sebagaimana pernyataan Rogers dalam bahwa pengetahuan/kognitif merupakan domain yang sangat penting bagi terberntuknya perilaku, dan perilaku yang didasari pengetahuan akan bertahan lebih langgeng dari pada perilaku yang tidak didasari pengetahuan (Abdullah \& Anissa, 2014).

Peningkatan pengetahuan yang dialami oleh responden setelah dilakukan pendidikan kesehatan ini sesuai dengan tujuan dari pendidikan kesehatan itu sendiri yaitu mengubah perilaku individuindividu, kelompok orang atau masyarakat dari halhal yang kurang baik (Herlina, 2019).

\section{c. Perbedaan tingkat pengetahuan antara kelompok eksperimen dengan kelompok kontrol}

Berdasarkan tabel 6 menunjukkan bahwa sebelum diberikan edukasi pada kelompok eksperimen dan kelompok kontrol didapatkan hampir seluruhnya (97\%) memiliki tingkat pengetahuan kurang dan sebagian kecil (3\%) memiliki tingkat pengetahuan kurang tentang PHBS Rumah Tangga.

Berdasarkan tabel 7 menunjukkan bahwa sesudah diberikan edukasi pada kelompok eksperimen hampir setengahnya $(48,5 \%)$ memiliki tingkat pengetahuan baik, hampir setengahnya $(27,3 \%)$ memiliki tingkat pengetahuan cukup dan sebagian kecil (24,2\%) memiliki tingkat pengetahuan kurang tentang PHBS Rumah Tangga. Pada kelompok kontrol menunjukkan hampir seluruhnya $(97 \%)$ memiliki tingkat pengetahuan kurang dan sebagian kecil (3\%) memiliki tingkat pengetahuan cukup tentang PHBS Rumah Tangga.

Peningkatan pengetahuan pada kelompok eksperimen dikarenakan telah mendapatkan edukasi tentang PHBS Rumah Tangga melalui media lembar balik. Sedangkan pada kelompok kontrol tidak mendapatkan edukasi sehingga tidak mengalami peningkatan pegetahuan tentang PHBS Rumah Tangga.

Media edukasi digunakan sebagai alat bantu untuk memberikan pesan dan menimbulkan perhatian terhadap suatu masalah sehingga akan mempengaruhi persepsi, pengetahuan dan sikap sasaran (Notoadmojo, 2012). Hal ini sesuai dengan hasil penelitian Saleh A (2017), bahwa ada pengaruh penyuluhan dengan media cetak leaflet terhadap peningkatan pengetahuan PHBS kader.

http://jurnalilmiah.stikescitradelima.ac.id/index.php/JI Vol.5 No.2 Januari 2022 


\section{SIMPULAN}

Berdasarkan hasil analisis penelitian dan pembahasan, maka dapat disimpulkan sebagai berikut:

1. Kader kesehatan Kebonsari Surabaya sebelum diberikan edukasi tentang PHBS Rumah Tangga didapatkan data pada kelompok eksperimen dan kelompok kontrol hampir seluruhnya (97\%) memiliki tingkat pengetahuan kurang dan sebagian kecil (3\%) memiliki tingkat pengetahuan cukup.

2. Kader kesehatan Kebonsari Surabaya sesudah diberikan edukasi tentang PHBS Rumah Tangga didapatkan data pada kelompok eksperimen hampir separohnya $(48,5 \%)$ memiliki tingkat pengetahuan baik, $(27,3 \%)$ memiliki tingkat pengetahuan cukup dan $(24,2 \%)$ memiliki tingkat pengetahuan kurang. Sedangkan pada kelompok kontrol, hampir seluruhnya (97\%) memiliki tingkat pengetahuan kurang dan sebagian kecil (3\%) memiliki tingkat pengetahuan cukup.

3. Ada pengaruh edukasi PHBS Rumah Tangga terhadap pengetahuan kader kesehatan di Kebonsari Surabaya.

\section{DAFTAR PUSTAKA}

Abdullah, D., \& Anissa, M. (2014). Jurnal Kesehatan Saintika Meditory Jurnal Kesehatan Saintika Meditory. Jurnal Kesehatan Saintika Meditory, 2(4657), 62-72.

Artanti, R. (2013). Pengaruh Pendidikan Kesehatan Tentang Perilaku Hidup Bersih Dan Sehat Tatatanan Rumah Tangga Terhadap Pengetahuan Ibu Rumah Tangga Di Desa Surodadi Kecamatan Candimulyo tahun 2012. Jurnal Komunikasi Kesehatan, vol 4 no 0(2013;4(02).). http://www.ejournal.akbidpurworejo.ac.id/index.php/jkk7/articl e/view/54

Buku PHBS pada masa AKB-No 2.pdf. (2020).

Damaiyanti, S. (2014). Hubungan Pengetahuan Ibu Rumah Tangga dan Peran Kader Dengan Perilaku Hidup Bersih dan Sehat (PHBS) dalam Rumah Tangga di Kelurahan Laing Wilayah Kerja Pusesmas Nanbalimo Keamatan Tanjung Harapan Kota Solo Tahun 2014. Jurnal Stikes Yarsi, Notoatmodjo 2010, 2.

Gani, H. A., Istiaji, E., \& Pratiwi, P. E. (2015). Perilaku Hidup Bersih dan Sehat (PHBS) Pada Tatanan Rumah Tangga Masyarakat Using (Studi Kualitatif di Desa Kemiren, Kecamatan Glagah, Kabupaten Banyuwangi). Jurnal IKESMA, 11(1), 26-35.
Herlina, S. dan M. (2019). Kesehatan Masyarakat Implementasi, Konsep, Skenario, Kasus, dan Dasar Hukum. Multimedia.

Notoatmodjo, S. (2010). Promosi Kesehatan dan Ilmu Perilaku. Rineka Cipta.

Notoatmodjo, S. (2014). Metodologi Penelitian Kesehatan. Rineka Cipta.

Nurroh, S. (2017). Filsafat Ilmu Assignment Paper of Filosophy of Geography Science. Universitas Gajah Mada.

Saleh, A., \& Kunoli, F. J. (2019). Pengaruh Penyuluhan Dan Pelatihan Melalui Media Leaflet Terhadap Pengetahuan Kader Phbs Di Kecamatan Ratolindo Kabupaten Tojo Una-Una. PROMOTIF: Jurnal Kesehatan Masyarakat, 8(2), 159-164. https://doi.org/10.31934/promotif.v8i2.498 